\title{
Storm-induced tree resistance and chemical differences in Norway spruce (Picea abies)
}

\author{
Tao Zhao • Halvor Solheim • Bo Långström • \\ Anna-Karin Borg-Karlson
}

Received: 13 June 2010 / Accepted: 8 November 2010 /Published online: 20 April 2011

(C) INRA and Springer Science+Business Media B.V. 2011

\begin{abstract}
- Introduction Windstorm is one of the most destructive environmental disturbance factors on forests, but its influence on conifer defense chemistry and susceptibility to insects and diseases is not well understood.

- Materials and methods We selected groups of 10 Norway spruce trees with short leaders, leaning stems, or no apparent damage 17 months after the largest storm ever recorded in Sweden. Trees were mass-inoculated with Ceratocystis polonica, a virulent blue stain fungus associated with the spruce bark beetle (Ips typographus) to estimate tree resistance. Terpene and phenolic composition in the bark was analyzed by gas chromatography-mass spectrometry, two-dimensional gas chromatography, and liquid chromatography.

- Results In contrast to our hypothesis, the results showed that trees with no apparent damage were more susceptible to C. polonica inoculation than short-leader and leaningstem trees. Chemical composition also differed between trees in different damage classes. (+)-3-carene and two unidentified stilbenes were higher, and taxifolin glycoside was lower in trees without apparent damage than in the
\end{abstract}

Handling Editor: François Lieutier

T. Zhao · A.-K. Borg-Karlson $(\bowtie)$

Department of Chemistry, Royal Institute of Technology,

10044 Stockholm, Sweden

e-mail: akbk@kth.se

H. Solheim

Norwegian Forest and Landscape Institute,

P.O. Box 115, 1431 Ås, Norway

B. Långström

Department of Ecology, Swedish University

of Agricultural Sciences,

P. O. Box 7044, 75007 Uppsala, Sweden others. The relative amount of $(-)-\alpha$-pinene was negatively correlated, whereas $(+)-3$-carene, sabinene, $(-)$-germacrene $D$, thunbergol and two unidentified stilbenes were positively correlated with fungal performance.

- Conclusions These results suggested that wind damage had increased resistance level of short-leader and leaning trees to $C$. polonica inoculation, and that change in terpene and phenolic composition in the bark could be at least partly responsible for the induced resistance. Different possible explanations for this unexpected finding are discussed.

Keywords Storm damage - Picea abies · Resistance . Terpenes $\cdot$ Phenolics

\section{Introduction}

Windstorms occur at irregular intervals in boreal forests and represent a major challenge for forest management. Swedish statistics indicate that storms and resulting tree damage have increased both in frequency and severity during the last century (Nilsson et al. 2004). In January 2005, "Gudrun"the largest storm felling recorded in Sweden-felled ca. 75 million cubic meters of mainly Norway spruce [Picea abies (L.) Karsten] forest in southern Sweden. In 2006-2008, ca. 3 million cubic meters of standing spruce was killed by Ips typographus (L.) (Col., Scolytinae) that had multiplied in the fallen trees in 2005 and attacked living trees from 2006 onwards (Långström et al. 2009). It is common knowledge that bark beetle outbreaks in Europe often develop after storm fellings, which provide abundant breeding material for the beetles in the form of windfalls and weakened standing trees. Following a storm felling and subsequent salvage logging, many trees at the edges of 
storm gaps are suddenly exposed — which may render them more susceptible to beetle attack. In addition, they may have more or less damaged root systems due to the bending forces of the windstorm. Root damage appears to be a common phenomenon in storm-damaged stands (Coutts 1986; Hintikka 1972; Nielsen and Knudsen 2004) and is generally thought to predispose trees to subsequent beetle attack due to reduced resistance. Impaired water uptake has often been considered the main effect of root damage, but other factors such as healing the injured roots and branches also cost energy and impair tree growth. Pathogenic fungi, like Heterobasidion annosum sensu lato (Fr.) Bref., which cause root and butt rot, may also benefit from trees with damaged root systems (see, e.g., Jactel and Van Halder 2004). However, little is known about the physiological and chemical changes in storm-damaged trees and how these may affect tree susceptibility to fungal or insect attack.

Conifer resistance against bark beetles and their associated fungi varies among individuals and stands due to age, physiological, and genetic differences. It may also change in response to biotic and abiotic stress factors such as ozone, drought, or fungal infection (Bonello et al. 1993; Faccoli 2009; Lieutier 2004; Lorio 1986; Raffa and Berryman 1983; Salle et al. 2008). Host resistance reactions involve histological and physiological changes in the phloem as well as an altered chemistry. The oleoresin is toxic to insects and microorganisms. It may also deter beetle invasion and impede fungal growth by its physical obstructive properties (Gershenzon and Dudareva 2007; Franceschi et al. 2005). In addition, some phenolics such as catechin, taxifolin, or resveratrol have antifeedant effects to I. typographus (Faccoli and Schlyter 2007) and an inhibitory effect on bark beetle-associated fungi (Lieutier 2004; Salle et al. 2008). Hence, some terpenes and phenols have been used as chemical markers of conifer resistance or susceptibility (Brignolas et al. 1995a, b, 1998; Lieutier et al. 2003; Zhao et al. 2010).

In early summer 2006, 17 months after the "Gudrun" windstorm in Sweden, many trees along storm-damaged stand edges were leaning over or had reduced leader shoot lengths, indicating water or other stress in the previous and/ or current year. This situation offered a possibility to study the relationship between storm damage and tree resistance to bark beetles and their associated blue stain fungi. To understand the mechanism responsible for resistance or susceptibility, we investigated the terpene and phenolic compositions of the trees and evaluated tree resistance by mass inoculation with Ceratocystis polonica (Siem.) C. Moreau, the most virulent fungal associate of I. typographus, which is used routinely to evaluate the resistance of individual Norway spruce trees (Christiansen 1985; Sandnes and Solheim 2002).

\section{Materials and methods}

\subsection{Field procedure and sample extraction}

The experiment was conducted at the Tönnersjöheden Experimental Forest $\left(56^{\circ} 41^{\prime} \mathrm{N}, 4^{\circ} 57^{\prime} \mathrm{E}\right)$, situated in southwestern Sweden. The study site was a ca. 30-year-old spruce stand at the northern edge of a storm gap following the storm "Gudrun" in January 2005. In early June 2006, 30 trees representing different damage categories were selected along the stand edge: 10 trees with no apparent damage symptoms, i.e., standing trees with normal height growth; 10 trees with reduced height growth in 2005 (short-leader trees); and 10 leaning trees with visible root damage, i.e., the root cake was partially detached from the ground. All study trees were growing within $5 \mathrm{~m}$ of the stand edge, and all were of the co-dominant tree class. On June 13, 2006, one phloem sample was taken at $1.3 \mathrm{~m}$ of stem height on each experimental tree with a $5-\mathrm{mm}$ cork borer and submerged into $0.5 \mathrm{ml}$ hexane in a 4-ml glass vial with Teflon-coated screw cap. After sampling, five trees in each category were massinoculated with actively growing mycelium of $C$. polonica on malt agar (2\% malt, $1.25 \%$ agar) at a density of 400 inoculation points per square meter, between 1.0 to $1.6 \mathrm{~m}$ of stem height, to assess tree resistance. Inoculations were done by removing a bark plug with a $5-\mathrm{mm}$ cork borer, inserting a similar sized inoculum into the hole and replacing the bark plug. The strain used was NFLI 1993-208/115 which had been isolated from a Norway spruce log inoculated with the bark beetle Polygraphus poligraphus L. (Krokene and Solheim 1996). The strain has been used in several inoculation studies (Christiansen et al. 1999; Krokene et al. 1999, 2001, 2003; Nagy et al. 2004; Zhao et al. 2010).

The inoculated trees were felled, and symptoms of fungal infection were measured on August 30, 2006. For each tree, six inoculation points distributed around $1.3 \mathrm{~m}$ of stem height were selected randomly, the outer bark around the inoculation points was removed with a knife to expose the reaction zones resulting from the fungal inoculation, and the vertical expansion of the phloem necrosis lesion was measured upwards and downwards. Leader lengths were measured for the years 2003-2006. Two thin stem discs were cut from the inoculated stem section 20 and $40 \mathrm{~cm}$ from the lower end and taken to the laboratory where the area of occluded and blue-stained sapwood was determined by a computer-connected planimeter. The proportion of dead and live cambium was measured along the outer perimeter of the discs. Tree rings for the years 2005 and 2006 were measured with the digital WinDENDRO ${ }^{\mathrm{TM}}$ system with an accuracy of $0.01 \mathrm{~mm}$. The relative height increment reduction in years 2005 or 2006 was calculated as: (height increment in the year-mean height increment in years 2003 and 2004)/mean height increment in years 2003 and 
$2004 \times 100$, and the relative radial growth was calculated as: growth in the year/mean growth in years 2003 and $2004 \times 100$.

The bark plug was extracted in hexane at room temperature for $48 \mathrm{~h}$. The extracts were then transferred to 2-ml sampling vials (Chromacol, UK) individually and kept at $-25^{\circ} \mathrm{C}$ until gas chromatography-mass spectrometry (GC-MS) analyses. The hexane extracted bark plugs were further extracted by $80 \%$ methyl alcohol in water $(v / v)$ for $24 \mathrm{~h}$, after washing with $1 \mathrm{ml}$ hexane for three times to remove resinous compounds (Brignolas et al. 1995a, b). The methanol extracts were then transferred to new sample vials and stored at $-25^{\circ} \mathrm{C}$.

\subsection{Terpene separation, identification, and quantification}

A Varian 3400 GC connected to a Finnigan SSQ 7000 MS was used for separation, identification and quantification of terpenes. A DB-WAX fused silica capillary column (J\&W Scientific, $30 \mathrm{~m}$ length, $0.25 \mathrm{~mm}$ i.d., and $0.25 \mu \mathrm{m}$ film thickness) was used, and the temperature program was set at $40^{\circ} \mathrm{C}$ for $4 \mathrm{~min}$, increasing to $220^{\circ} \mathrm{C}$ at a rate of $4^{\circ} \mathrm{C} \mathrm{min}^{-1}$, and then remaining constant at $220^{\circ} \mathrm{C}$ for $12 \mathrm{~min}$. A split/splitless injector with a 30-s splitless injection of $1 \mu \mathrm{l}$ was used with a temperature of $215^{\circ} \mathrm{C}$. The terpene hydrocarbons were identified by comparing retention times and mass spectra with available authentic standards, or by comparing retention indexes and the mass spectra with Massfinder 3.0 (Hochmuth Scientific Consulting, Germany) and the reference library of the National Institute of Standards and Technology. The relative amount of each terpene was calculated based on the peak area divided by the total area of all the peaks and expressed in percentage.

The enantiomeric composition of the most behaviorrelevant monoterpenes for I. typographus: $\alpha$-pinene and limonene was analyzed by a 2D Varian 3400 GC system (Borg-Karlson et al. 1993), using the same procedure as in our previous work (Zhao et al. 2010). 3-Carene was considered to be present as pure (+)-enantiomer and germacrene $\mathrm{D}$ as pure (-)-enantiomer based on previous studies (Persson et al. 1996; Stranden et al. 2003). The enantiomeric composition of a specific terpene was defined as the GC peak area of the $(-)$-enantiomer divided by the sum of the areas of the $(+)$ - and (-)-enantiomers, and normalized to 100 . The relative amount of a specific enantiomer was calculated by multiplying the ratio of this enantiomer by the relative amount of the corresponding monoterpene obtained by GC-MS.

\subsection{Phenol separation, identification, and quantification}

The composition of phenols was analyzed by HP 1090 LC fitted with ultraviolet/visible spectrophotometer (UV/vis) diode array detector. A Discovery C18 reversed (Supelco, USA) phase HPLC column $(25 \mathrm{~cm} \times 4.6 \mathrm{~mm}, 5 \mu \mathrm{m}$ particle size $)$ was used for the separations. The mobile phases were acetonitrile and acetic acid-water $(0.1 / 100, v / v)$. The step gradient program used in this experiment was modified based on the procedure described by Brignolas et al. (1995a, b): 5 min with 95\% acetic acid solution and 5\% acetonitrile, then $43 \mathrm{~min}$ with linear increase in acetonitrile up to $25 \%$, followed by another linear increase up to $70 \%$ in $10 \mathrm{~min}$. Conditions were kept constant for another $10 \mathrm{~min}$, then the gradient was returned to the initial conditions within $5 \mathrm{~min}$. The flow rate was $1 \mathrm{ml} \mathrm{min}{ }^{-1}$, the injection volume was $20 \mu \mathrm{l}$, and the analyses were conducted at room temperature $\left(26-28^{\circ} \mathrm{C}\right)$. The spectra were recorded from 190 to $400 \mathrm{~nm}$, and the quantification was done at $280 \mathrm{~nm}$. Compounds were identified by comparing the retention time and UV spectrum with reference phenols gifted from INRA, Orléans, France. The relative amount of specific phenol was calculated as described for terpenes.

\subsection{Statistical analyses}

The relative amounts of all the quantified terpenes or phenols (normalized to $100 \%$ ) were subjected to principal component analysis (PCA) to evaluate the variation between samples (Canoco 4.5, Biometris Plant Research International, the Netherlands). Fungal performance and chemical amount among the three groups were compared using one-way ANOVA. If treatments were significantly different $(p<0.05)$, means were separated using least significant difference (LSD) at $p=0.05$ (Statistica 6.0, Statsoft, Inc., USA). Data were arcsin-transformed before statistic tests to correct for the deviation from normality. Correlation between chemicals and fungal performance were calculated by means of Pearson product-moment correlation coefficient.

\section{Results}

\subsection{Storm damage and tree growth}

The height increment of all trees was lower in 2005 than in 2003 and 2004, and this reduction was significantly larger in trees with short leaders and leaning stems (Table 1). The trees with no apparent damage, however, also displayed reduced growth, indicating that they too were affected by the storm or that 2005 , generally, was a poorer growth year than the previous ones (This issue will be elaborated in the discussion below). There were no significant differences in leader length reduction between tree groups in 2006, but all tree groups displayed greatly reduced growth, which implies that all the trees were suffering from storm damage or that the inoculation itself had affected height growth.

In contrast, radial growth of the study trees showed a different pattern as the short-leader trees grew better in 2005 and 2006 than prior to the storm and better than the two other groups which displayed reduced growth in both years. 
Table 1 The tree height, diameter at $1.3 \mathrm{~m}$ stem height $(\mathrm{DBH}$, and relative height increment reduction in Norway spruce trees with no apparent damage, short leader, or leaning stem

\begin{tabular}{|c|c|c|c|c|c|c|}
\hline \multirow[t]{2}{*}{ Groups } & \multirow[t]{2}{*}{ Height, $\mathrm{m}$} & \multirow[t]{2}{*}{$\mathrm{DBH}, \mathrm{cm}$} & \multicolumn{2}{|c|}{ Height increment reduction, $\%^{\mathrm{a}}$} & \multicolumn{2}{|c|}{ Relative radial growth, $\%{ }^{\mathrm{b}}$} \\
\hline & & & 2005 & 2006 & 2005 & 2006 \\
\hline No apparent damage & $12.6 \pm 0.8$ & $14.66 \pm 2.97$ & $37.8 \pm 6.7 \mathrm{a}$ & $83.3 \pm 2.8$ & $88.3 \pm 10.1$ & $93.7 \pm 9.7 \mathrm{a}$ \\
\hline Short leader & $13.8 \pm 0.6$ & $14.41 \pm 2.72$ & $78.9 \pm 4.5 \mathrm{~b}$ & $91.0 \pm 3.7$ & $112.8 \pm 26.0$ & $140.3 \pm 45.0 \mathrm{a}$ \\
\hline Leaning stem & $11.5 \pm 0.8$ & $11.13 \pm 2.57$ & $71.6 \pm 6.3 \mathrm{~b}$ & $89.3 \pm 3.2$ & $54.4 \pm 11.4$ & $48.2 \pm 4.1 \mathrm{~b}$ \\
\hline$F$ & 3.38 & 2.94 & 13.71 & 1.35 & 1.263 & 8.03 \\
\hline$p$ & 0.068 & 0.093 & $<0.01$ & 0.30 & 0.324 & $<0.01$ \\
\hline
\end{tabular}

The data were collected on August 30 (11 weeks after fungal inoculation) and expressed as means \pm 1 SE $(n=5)$. Means followed by different letters in a column are significantly different by the LSD test at $p=0.05$

${ }^{\text {a }}$ Height increment reduction $=($ height increment in the year - mean height increment in 2003 and 2004)/mean height increment in 2003 and $2004 \times$ 100

${ }^{\mathrm{b}}$ Relative radial growth $=$ radial growth in the year/mean radial growth in years 2003 and $2004 \times 100$

\subsection{Fungal performance after storm damage}

There were significant differences between treatments in mean proportion of dead cambium $\left(F_{2,12}=4.826, p=0.029\right)$, occluded sapwood $\left(F_{2,12}=3.935, p=0.049\right)$, and blue-stained sapwood $\left(F_{2,12}=12.751, p<0.01\right)$ (Fig. 1). Trees with no apparent damage always had significantly more severe symptoms than storm-damaged trees, and there was little difference between leaning-stem and short-leader trees (Fig. 1). However, no significant difference was observed in phloem necrosis length between the three categories of trees (data not shown).

\subsection{Chemical composition after storm damage}

The general pattern of terpene composition was similar for all trees, but some differences in terpene composition were

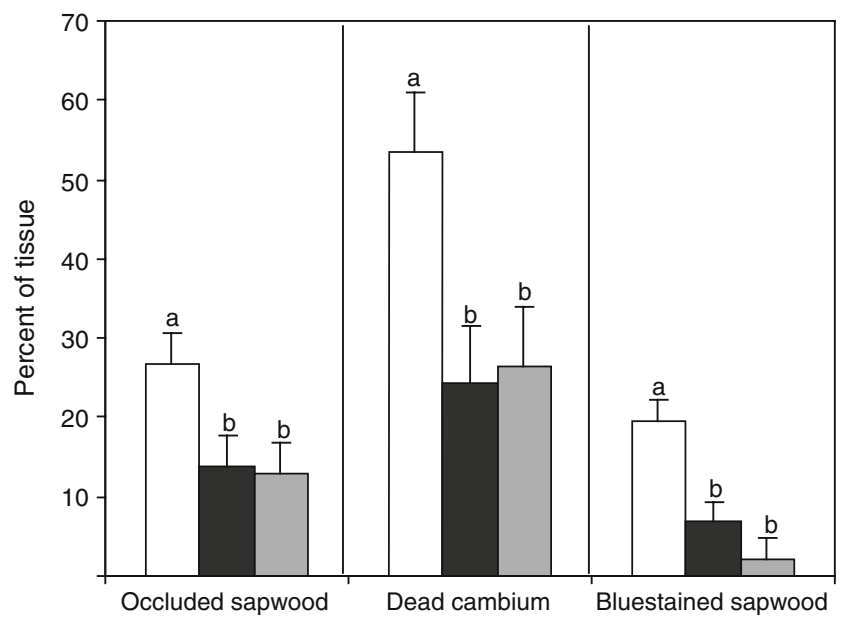

Fig. 1 Symptoms of $C$. polonica infection in Norway spruce trees with no apparent damage (white bars), short leader (black bars), and leaning stem (gray bars), 11 weeks after inoculation. The data were collected from each of 5 trees and expressed as mean +1 SE. Bars with different letters were significantly different by LSD test at $p=0.05$ observed between the three categories of trees. Specifically, the amounts of $(+)$-3-carene $\left(F_{2,27}=4.501, p=0.021\right)$, myrcene $\left(F_{2,27}=3.699, p=0.039\right)$, and germacrene D-4-ol $\left(F_{2,27}=\right.$ $6.972, p<0.01)$ varied between the three categories. $(+)-3-$ Carene was significantly higher in trees without apparent damage than in leaning-stem $(p<0.01)$ and short-leader trees $(p=0.046)$. In addition, the amount of $\beta$-pinene was significantly higher than $\alpha$-pinene in trees with no apparent damage $(t=3.548, p<0.01)$, whereas no differences were detected in short-leader and leaning trees. Accordingly, the ratio of (-)- $\alpha$ pinene to $\beta$-pinene was significantly lower in trees without apparent damage than the other two categories (Fig. 2).

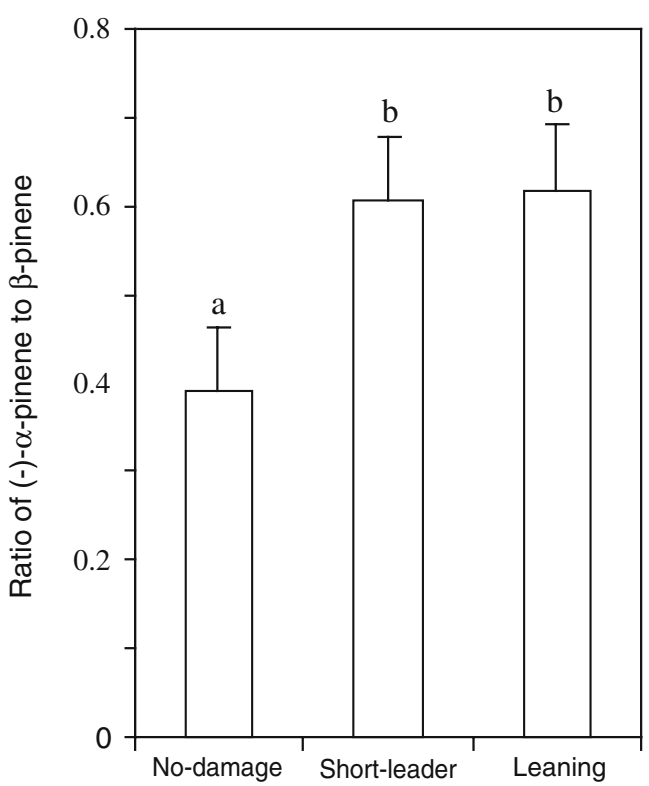

Fig. 2 The ratio of (-)- $\alpha$-pinene to $\beta$-pinene in Norway spruce trees with no apparent damage, short leader, and leaning stem, 17 months after the storm "Gudrun". Data were collected from trees inoculated $C$. polonica $(n=5)$ and expressed as untransformed mean +1 SE. Bars with different letters were significantly different by LSD test at $p=0.05$ 
The trees without apparent damage thus separated from others in a PCA plot (Fig. 3).

The phenolic composition differed extensively between trees with different symptoms. The relative amount of taxifolin glycoside was higher in leaning-stem and shortleader trees than trees without apparent damage, and two unknown stilbenes were higher in trees with no apparent damage than in others (Table 2). These differences separated trees with no apparent damage from others in PCA plots, based on the relative amounts of the phenols (Fig. 3).

3.4 Relationship between chemical composition and C. polonica performance

$(-)-\alpha$-Pinene, sabinene, $(+)-3$-carene, $(-)$-germacrene $\mathrm{D}$, and thunbergol were either negatively or positively correlated with fungal performance. The proportion of $(-)-\alpha$-pinene was negatively correlated with the percentage of occluded sapwood $(r=-0.560, p=0.0382)$ and dead cambium $(r=-0.528, p=0.0432)$, whereas $(+)-3$ carene, sabinene, $(-)$-germacrene $\mathrm{D}$, and thunbergol were positively correlated with one or more symptoms of fungal infection. In addition, two unidentified stilbenes were positively correlated with blue-stained sapwood (Table 3).

\section{A}

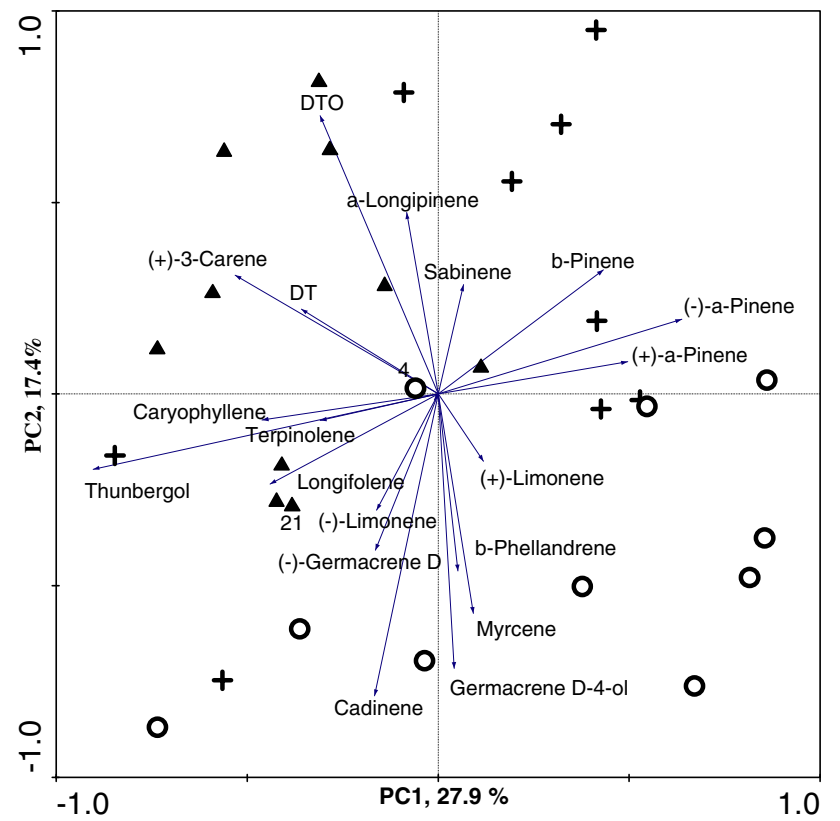

Fig. 3 PCA plot based on the relative amounts (normalized to $100 \%$ ) of all the quantified terpenes (a) or phenols (b) in the phloem of Norway spruce trees with no apparent damage (triangle), short leader (circle), and leaning stem (cross), 17 month after the storm "Gudrun." Each symbol represents one tree. The arrows indicate the contribution

\section{Discussion}

This experiment clearly indicates that storm damage resulted in differences in terpene and phenolic composition, and resistance to C. polonica inoculation in Norway spruce trees with different damage symptoms 17 months after a storm event. Contrary to our hypothesis, the obviously damaged trees tended to be more resistant to fungal inoculation than the seemingly undamaged trees. This finding was unexpected since root damage has generally been seen as a factor reducing tree vigor (Coutts 1986; Hintikka 1972; Nielsen and Knudsen 2004) and hence predisposing trees to beetle attack (Wermlinger 2004). In spring 2010, we measured leader lengths in trees felled in a nearby stand in order to clarify the height growth conditions before and after the storm in 2005. Trees from the interior part of the stand displayed no growth reduction in 2005 compared to 2004 , and a $20 \%$ reduction in 2006 , probably due to the exceptionally dry summer (cf. Långström et al. 2009). Trees at the stand edge, however, already grew ca. $40 \%$ less in 2005 and ca. $50 \%$ less in the following year, compared to the year before the storm. Since trees inside a stand should be less affected by the storm than edge trees, it indicates that our no-damage trees were also affected by the storm in 2005 and that the effect persisted and was exacerbated in 2006 by the weather

B

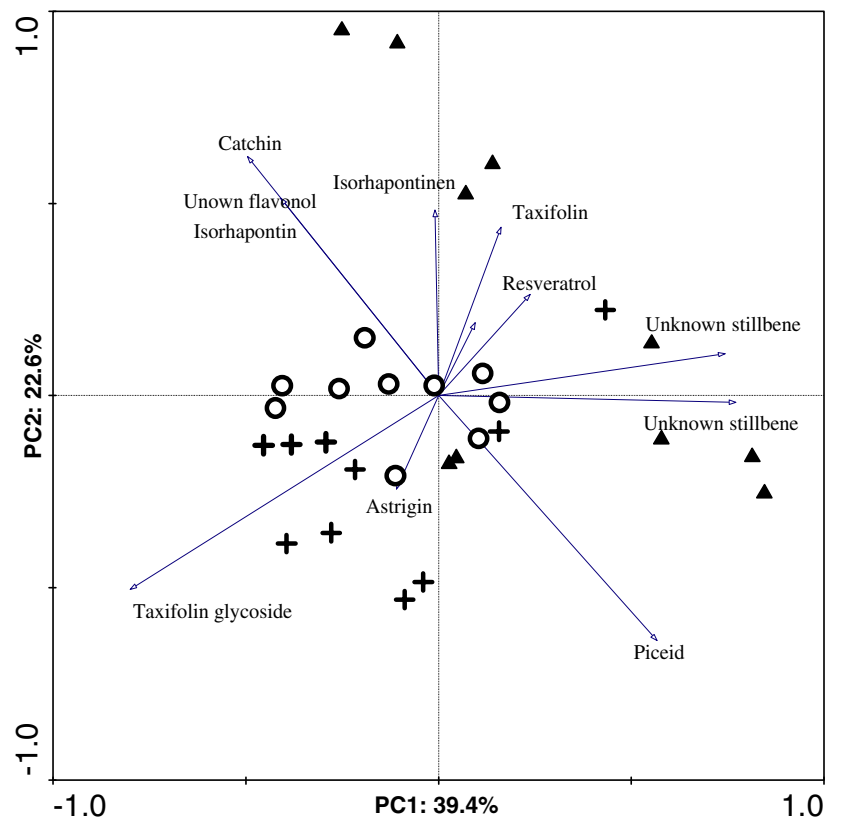

of terpenes to the principal components. In a, the first principal component (PC1) explained $27.9 \%$ and the second component (PC2) explained $17.4 \%$ of the sample variation. In $\mathbf{b}, \mathrm{PC} 1$ explained $39.4 \%$ and $\mathrm{PC} 2$ explained $22.6 \%$ of the sample variation 
Table 2 Relative amounts of terpene and phenol hydrocarbons in stem bark of Norway spruce trees with no apparent damage, short leader, or leaning stem, 17 months after the storm "Gudrun"

Data are collected from the trees with fungal inoculation $(n=5)$ and presented as untransformed means \pm 1 SE. Means followed by different letters in a row are significantly different by the LSD test at $p=0.05$

\begin{tabular}{|c|c|c|c|}
\hline Compounds & No apparent damage & Short leader & Leaning stem \\
\hline \multicolumn{4}{|l|}{ Terpenoid compounds } \\
\hline$(-)-\alpha$-Pinene & $14.15 \pm 0.68$ & $21.28 \pm 2.42$ & $17.84 \pm 1.44$ \\
\hline$(+)-\alpha$-Pinene & $11.22 \pm 1.35$ & $14.24 \pm 1.59$ & $12.48 \pm 1.83$ \\
\hline$\beta$-Pinene & $35.31 \pm 3.57$ & $31.38 \pm 3.61$ & $31.16 \pm 1.78$ \\
\hline Sabinene & $0.87 \pm 0.32$ & $0.41 \pm 0.17$ & $0.21 \pm 0.14$ \\
\hline$(+)$-3-Carene & $1.29 \pm 0.32 \mathrm{a}$ & $0.31 \pm 0.15 \mathrm{~b}$ & $0.36 \pm 0.15 \mathrm{~b}$ \\
\hline Myrcene & $2.05 \pm 0.26$ & $2.04 \pm 0.26$ & $1.42 \pm 0.46$ \\
\hline$(-)$-Limonene & $0.84 \pm 0.10$ & $1.57 \pm 0.53$ & $1.02 \pm 0.20$ \\
\hline$(+)$-Limonene & $0.69 \pm 0.06$ & $1.01 \pm 0.32$ & $0.71 \pm 0.11$ \\
\hline$\beta$-Phellandrene & $7.66 \pm 1.24$ & $5.99 \pm 0.71$ & $6.71 \pm 1.62$ \\
\hline Terpinolene & $0.27 \pm 0.08$ & $0.31 \pm 0.09$ & $0.17 \pm 0.08$ \\
\hline$\alpha$-Longipinene & $0.43 \pm 0.18$ & $0.46 \pm 0.22$ & $0.45 \pm 0.12$ \\
\hline$\alpha$-Gurjunene & $0.72 \pm 0.32$ & $0.60 \pm 0.20$ & $0.52 \pm 0.30$ \\
\hline Longifolene & $0.96 \pm 0.35$ & $0.68 \pm 0.34$ & $1.65 \pm 0.71$ \\
\hline$(E)$ - $\beta$-caryophyllene & $0.30 \pm 0.12$ & $0.52 \pm 0.39$ & $0.93 \pm 0.28$ \\
\hline$(-)$-Germacrene D & $3.80 \pm 1.12$ & $1.49 \pm 0.66$ & $1.56 \pm 0.55$ \\
\hline$\delta$-Cadinene & $1.12 \pm 0.39$ & $1.67 \pm 0.56$ & $0.85 \pm 0.40$ \\
\hline Germacrene D-4-ol & $1.82 \pm 0.78 \mathrm{a}$ & $5.40 \pm 2.21 \mathrm{~b}$ & $2.30 \pm 0.55 \mathrm{a}$ \\
\hline Thunbergol & $3.75 \pm 1.60$ & $2.29 \pm 1.08$ & $3.14 \pm 1.45$ \\
\hline Abienol & $6.33 \pm 1.72$ & $5.97 \pm 3.30$ & $9.61 \pm 0.78$ \\
\hline Others & $4.05 \pm 1.48$ & $3.18 \pm 0.93$ & $2.34 \pm 1.37$ \\
\hline \multicolumn{4}{|l|}{ Phenolic compounds } \\
\hline Catechin & $7.34 \pm 30.5$ & $13.76 \pm 7.61$ & $3.82 \pm 0.92$ \\
\hline Unknown flavone & $2.63 \pm 1.75$ & $2.74 \pm 0.39$ & $3.27 \pm 0.72$ \\
\hline Astringin & $1.76 \pm 0.41$ & $3.15 \pm 0.56$ & $4.59 \pm 2.99$ \\
\hline Taxifolin glycoside & $3.55 \pm 1.45 \mathrm{a}$ & $16.51 \pm 1.33 \mathrm{~b}$ & $26.76 \pm 9.01 \mathrm{~b}$ \\
\hline Piceid & $14.53 \pm 4.38$ & $6.76 \pm 0.37$ & $8.28 \pm 1.59$ \\
\hline Taxifolin & $5.01 \pm 0.54$ & $5.34 \pm 0.85$ & $4.74 \pm 1.37$ \\
\hline Isorhapontin & $3.04 \pm 0.30$ & $2.65 \pm 0.32$ & $2.95 \pm 0.41$ \\
\hline Unknown stilbene & $10.38 \pm 1.56 \mathrm{a}$ & $3.03 \pm 0.59 \mathrm{~b}$ & $3.66 \pm 0.13 \mathrm{~b}$ \\
\hline Unknown stilbene & $11.72 \pm 4.76 \mathrm{a}$ & $2.94 \pm 0.46 \mathrm{~b}$ & $3.97 \pm 0.68 \mathrm{~b}$ \\
\hline Resveratrol & $33.70 \pm 4.61$ & $32.91 \pm 1.39$ & $31.98 \pm 5.42$ \\
\hline Isorhapontinen & $6.27 \pm 1.20$ & $10.21 \pm 2.18$ & $5.98 \pm 1.69$ \\
\hline
\end{tabular}

Table 3 Correlation coefficient between relative amount of chemicals and symptom of fungal infection

\begin{tabular}{|c|c|c|c|c|}
\hline Compounds & Dead cambium & Occluded sapwood & Blue-stained sapwood & Phloem necrosis length \\
\hline$(-)$ - $\alpha$-Pinene & $-0.5277^{*}$ & $-0.5595 *$ & -0.4138 & -0.3573 \\
\hline Sabinene & $0.5954 *$ & 0.3566 & 0.3070 & 0.1242 \\
\hline$(+)$-3-Carene & $0.5422 *$ & $0.6091 *$ & $0.6015^{*}$ & 0.3320 \\
\hline (-)-Germacrene D & 0.4783 & $0.5407 *$ & 0.4475 & 0.4214 \\
\hline Thunbergol & 0.4035 & 0.3872 & $0.5610 *$ & 0.2366 \\
\hline Unknown stilbene & 0.4590 & 0.5133 & $0.6099 *$ & 0.1736 \\
\hline Unknown stilbene & 0.4717 & 0.4799 & $0.6577^{*}$ & 0.1762 \\
\hline
\end{tabular}

The data were collected from each of five trees with no apparent damage, short leader and leaning stem. Boldface numbers indicate significant correlation between terpene and fungal infection

${ }^{*} p<0.05$ 
conditions. Therefore, there was no real undamaged control tree in our experiment. Our results, instead of demonstrating the general influence of windstorm to conifers, show the differences between three groups of trees with different damage levels after the storm.

Our radial growth results, however, indicate that the short-leader trees allocated relatively more carbohydrates to radial growth than the other two groups. This could reflect different allocation patterns between the tree groups in accordance with the growth-differentiation balance hypothesis (Lorio 1986). Hence, reduced height growth may not always, as we assumed, reflect reduced tree vigor although it generally is linked to poorer growth conditions. Thus, the short-leader trees may have been less stressed than we anticipated. However, this is unlikely to be true for the leaning trees which had ca. half of their roots broken and largely detached from the soil.

In our study, we found no differences in phloem necrosis lengths between our tree categories, whereas we clearly got higher cambium and sapwood invasion in the seemingly undamaged trees. It is obvious that the trees without apparent damage were closer to being killed than the more storm-damaged ones and consequently were less resistant to the fungal inoculations. This indicates that cambium and sapwood symptoms are also valuable parameters in evaluation of Norway spruce resistance to $C$. polonica inoculation. However, since Lieutier et al. (2009) argue that the major role of fungi on bark beetle colonization is to stimulate tree resistance, the relevance of sapwood parameters to tree resistance against bark beetle still needs further confirmation.

Our results, somehow, are challenging the well-established paradigm that bark beetle attacks develop when weakened host material becomes available following windstorms (Nilsson et al. 2004). However, our result was in line with the observation from Norway (Worrell 1983). There, a storm in 1969 felled $3-10 \%$ of the growing stock resulting in a beetle outbreak and consequent tree mortality in the early 1970s. However, the major bark beetle outbreak and tree mortality occurred in the late 1970s after 2 years of severe drought in 1975 and 1976. Notably, the severely affected areas were not those primarily affected by the windstorm but rather areas affected by drought.

A severe storm is a dramatic event, and trees not windfelled but stressed may respond in a similar way as a wounding or as a sudden drought. It has repeatedly been shown that moderate drought stress may render trees more resistant to fungal inoculation than well-watered control trees (Christiansen and Glosli 1996; Croisé et al. 1998; Lieutier 2004) and that the trees were more resistant in the season with the maximum soil water deficit (Lorio 1986; Salle et al. 2008). According to Nielsen and Knudsen (2004) root damage is a persistent condition which affects water uptake and tree vigor several years after initial damage. Our study was done 17 months after the storm, and the damaged trees would still have suffered from root damage inflicted during the storm. The wound induction in Norway spruce seems to act locally (Krokene et al. 1999), but the signal for induction of traumatic resin ducts (an indicator of induced resistance) may spread at a speed of $2.5 \mathrm{~cm}$ per day (Krekling et al. 2004). Hence, in 17 months, damage-induced acquired resistance may have spread from wounded roots to the trunk where the inoculations were done.

The relatively poor performance of the fungus in stormdamaged trees is corroborated by the chemical differences between tree groups. For terpenes, the amount of 3-carene was significantly higher, and the ratio of $(-)-\alpha$-pinene to $\beta$-pinene was significantly lower in no-damage trees than trees from the other two groups. 3-Carene was positively correlated with fungal infection, $(-)-\alpha$-pinene negatively correlated with fungal infection, and $\beta$-pinene showed no correlation with symptoms of fungal infection. As such, the higher 3-carene and lower $(-)-\alpha$-pinene to $\beta$-pinene ratio could partly explain the better fungal performance in no-damage trees.

It is generally considered that astringin and isorhapontin are the major phenolic components in Norway spruce phloem (Brignolas et al. 1995a, b, 1998; Lieutier et al. 2003; Viiri et al. 2001). We found the same pattern from unwounded seedlings of Norway spruce by using the same extraction and analyses methods (T. Zhao et al., unpublished data). However, very moderate amounts of those two stilbenes were detected in this study. Instead, resveratrol was rather high in all the trees and taxifolin glycoside was higher in leaning-stem and short-leader trees than trees without apparent damage. Resveratrol is an antifeedant to I. typographus (Faccoli and Schlyter 2007) and inhibited growth of bark beetle-associated fungi Ophiostoma piceaperdum and Ophiostoma bicolor on malt agar medium (Sallé et al. 2005). It was rare or absent in unwounded Norway spruce phloem but was highly induced by fungal infection (Evensen et al. 2000; Brignolas et al. 1995a, b, 1998; Viiri et al. 2001). Thus, the high proportion of resveratrol in the phloem of our experimental trees probably indicated that the phenolic defense in all the experimental trees had been induced and thus rendered them less suitability to I. typographus and its associated fungi. Similarly, taxifolin glycoside was only detected from the phloem of resistant Norway spruce clones and the amount was related to tree resistance against C. polonica (Brignolas et al. 1995a, b, 1998). Here, we found that the proportion of taxifolin glycoside was higher in leaning- and short-leader trees which showed a higher resistance to $C$. polonica inoculation, and further confirmed taxifolin glycoside could be related with the Norway spruce resistance to C. polonica.

In conclusion, this study indicated that storm-damaged trees were more resistant to fungal inoculation than less 
damaged trees 17 months after a storm event. The underlying mechanisms are poorly understood. Since we do not have terpene, phenol, and resistance data for the study trees prior to the windstorm, we cannot exclude the possibility that differences may have existed between the tree categories before the windstorm. The experiment should hence be repeated on a larger scale including a broader spectrum of damage classes and at different time intervals following a storm event.

Acknowledgments The present study was funded by FORMAS (to akbk and BL) and Skog og landskap (to HS). We thank Paal Krokene for constructive comments to the manuscript, Douglas Jones for linguistic revision, and Morgan Erixon, Ulf Johansson, and Olaug Olsen for advice and technical assistance. Special thanks to Annie Yart for providing us with reference phenols.

\section{References}

Bonello P, Heller W, Sandermann H (1993) Ozone effects on rootdisease susceptibility and defence responses in mycorrhizal and non-mycorrhizal seedlings of Scots pine (Pinus sylvestris L.). New Phytol 124:653-663

Borg-Karlson A-K, Lindström M, Persson M, Norin T, Valterová I (1993) Enantiomeric composition of monoterpene hydrocarbons in different tissues of Norway spruce, Picea abies (L.) Karst: a multidimnesional gas chromatography study. Acta Chem Scand 47:138-144

Brignolas F, Lieutier F, Sauvard D, Yart A, Drouet A, Claudot AC (1995a) Changes in soluble-phenol content of Norway spruce (Picea abies) phloem in response to wounding and inoculation with Ophiostoma polonicum. Eur J For Pathol 25:253-265

Brignolas F, Lacroix B, Lieutier F, Sauvard D, Drouet A, Claudot AC, Yart A, Berryman AA, Christiansen E (1995b) Induced responses in phenolic metabolism in two Norway spruce clones after wounding and inoculations with Ophiostoma polonicum, a bark beetle-associated fungus. Plant Physiol 109:821-827

Brignolas F, Lieutier F, Sauvard D, Christiansen E, Berryman AA (1998) Phenolic predictors for Norway spruce resistance to the bark beetle Ips typographus (Coleoptera: Scolytidae) and an associated fungus, Ceratocystis polonica. Can J For Res 28:720 728

Christiansen E (1985) Ips/Ceratocystis-infection of Norway spruce: what is a deadly dosage? Z Angew Entomol 99:6-11

Christiansen E, Glosli AM (1996) Mild drought enhances the resistance of Norway spruce to a bark beetle-transmitted bluestain fungus. USDA For. Serv. Gen. Tech. Rep. NC-183, St. Paul, pp. 192-199

Christiansen E, Krokene P, Berryman AA, Franceschi VR, Krekling T, Lieutier F, Lonneborg A, Solheim H (1999) Mechanical injury and fungal infection induce acquired resistance in Norway spruce. Tree Physiol 19:355-381

Coutts MP (1986) Components of tree stability in Sitka spruce on peaty gley soil. Forestry 59:173-197

Croisé L, Lieutier F, Dreyer E (1998) Scots pine responses to number and density of inoculation points with Leptographium wingfieldii Morelet, a bark beetle-associated fungus. Ann For Sci 55:497-506

Evensen PC, Solheim H, Høiland K, Stenersen J (2000) Induced resistance of Norway spruce, variation of phenolic compounds and their effects on fungal pathogens. For Pathol 30:97-108
Faccoli M (2009) Effect of weather on Ips typographus (Coleoptera Curculionidae) phenology, voltinism, and associated spruce mortality in the southeastern Alps. Environ Entomol 38:307-316

Faccoli M, Schlyter F (2007) Conifer phenolic resistance markers are bark beetle antifeedant semiochemicals. Agric For Entomol 9:237-245

Franceschi VR, Krokene P, Christiansen E, Krekling T (2005) Anatomical and chemical defenses of conifer bark against bark beetles and other pests. New Phytol 167:353-376

Gershenzon J, Dudareva N (2007) The function of terpene natural products in the natural world. Nat Chem Biol 3:408-414

Hintikka V (1972) Wind-induced root movements in forest trees. Comm Inst For Fenniae 76:56

Jactel H, Van Halder I (2004) Les conséquences de la tempête de 1999 en forêt Aquitaine: la catastrophe ne s'est pas produite, Ministère de l'agriculture de l'alimentation et de la Pêche et des affaires rurales (DGFAR), Les cahiers du DSF, 1-2003/2004. DGFAR, Paris, pp 75-78

Krekling T, Franceschi VR, Krokene P, Solheim H (2004) Differential anatomical responses of Norway spruce stem tissues to sterile and fungus infected inoculations. Trees 18:1-9

Krokene P, Christiansen E, Solheim H, Franceschi VR, Berryman AA (1999) Induced resistance to pathogenic fungi in Norway spruce. Plant Physiol 121:565-569

Krokene P, Solheim H (1996). Fungal associates of five bark beetle species colonizing Norway Spruce. Can J For Res 26:2115-2122

Krokene P, Solheim H, Christiansen E (2001) Induction of disease resistance in Norway spruce (Picea abies) by necrotizing fungi. Plant Physiol 50:230-233

Krokene P, Solheim H, Krekling T, Christiansen E (2003) Inducible anatomical defense responses in Norway spruce stems and their possible role in induced resistance. Plant Physiol 23:191-197

Långström B, Lindelöw Å, Schroeder M, Björklund N, Öhrn P (2009) The spruce bark beetle outbreak in Sweden following the January-storms in 2005 and 2007. In: Kunca A, Zubrik M (eds) Proceedings of the IUFRO Working Party 7.03.10, pp $13-19$

Lieutier F (2004) Host resistance to bark beetles and its variations. In: Lieutier F, Day KR, Battisti A, Grégoire J-C, Evans HF (eds) Bark and wood boring insects in living trees in Europe, a synthesis. Kluwer Academic Publisher, Dordrecht, pp 135-180

Lieutier F, Brignolas F, Sauvard D, Yart A, Galet C, Brunet M, van de Sype H (2003) Intra- and inter-provenance variability in phloem phenols of Picea abies and relationship to a bark beetle associated fungus. Tree Physiol 23:247-256

Lieutier F, Yart A, Sallé A (2009) Stimulation of tree defenses by ophiostomatoid fungi can explain attack success of bark beetles on conifers. Ann For Sci 66(801):22

Lorio PL (1986) Growth-differentiation balance: a basis for understanding southern pine beetle-tree interactions. For Ecol Manage 14:259-273

Nagy N, Fossdal CG, Krokene P, Krekling T, Lönneborg A, Solheim $\mathrm{H}$ (2004) Induced responses to pathogen infection in Norway spruce phloem: changes in polyphenolic parenchyma cells, chalconesynthase transcript levels and peroxidase activity. Tree Physiol 24:505-515

Nielsen CN, Knudsen MA (2004) Stormstabilitet og sundhed i en rødgransskærm. 7 års resultater efter skærmstillingen. Dansk Skovbrugs Tidsskrift 89:115-128 (In Danish only)

Nilsson C, Stjernquist I, Bärring L, Schlyter P, Jönsson AM, Samuelsson H (2004) Recorded storm damage in Swedish forests 1901-2000. For Ecol Manag 199:165-173

Persson M, Sjödin K, Borg-Karlson AK, Norin T, Ekberg I (1996) Relative amount and enantiomeric compositions of monoterpene 
hydrocarbons in xylem and needle of Picea abies. Phytochemistry 42:1289-1297

Raffa KF, Berryman AA (1983) The role of host plant resistance in the colonization behaviour and ecology of bark beetles (Coleoptera: Scolytidae). Ecol Monogr 53:27-49

Salle A, Ye H, Yart A, Lieutier F (2008) Seasonal water stress and the resistance of Pinus yunnanensis to a bark-beetle-associated fungus. Tree Physiol 28:679-687

Sallé A, Monclus R, Yart A, Lieutier F (2005) Effect of phenolic compounds on the in vitro growth of two fungi associated with Ips typographus. For Pathol 35:298-304

Sandnes A, Solheim H (2002) Variation in tree size and resistance to Ceratocystis polonica in a monoclonal stand of Norway spruce. Scand J For Res 17:522-528

Stranden M, Liblikas I, König WA, Almaas TJ, Borg-Karlson A-K, Mustaparta H (2003) Germacrene D receptor neurones in three species of heliothine moths: structure-activity relationships. J Comp Physiol A 189:563-577

Viiri H, Annila E, Kitunen V, Niemelä P (2001) Induced responses in stilbenes and terpenes in fertilized Norway spruce after inoculation with blue-stain fungus, Ceratocystis polonica. Tree 15:112-122

Wermlinger B (2004) Ecology and management of the spruce bark beetle Ips typographus - a review of recent research. For Ecol Manag 202:67-82

Worrell R (1983) Damage by the spruce bark beetle in Southern Norway 1970-80: a survey, and factors affecting its occurrence. Medd Nor Inst Skogforsk 38:1-34

Zhao T, Krokene P, Björklund N, Långström B, Solheim H, Christiansen E, Borg-Karlson A-K (2010) The influence of Ceratocystis polonica inoculation and methyl jasmonate application on terpene chemistry of Norway spruce, Picea abies. Phytochemistry 71:1332-1341 